\title{
STRATEGI PENANAMAN KARAKTER DISIPLIN SANTRI
}

\author{
Nurwahyudin \\ Institut Agama Islam (IAIN) Kendari \\ nurwahyudin1979@gmail.com \\ Supriyanto \\ Institut Agama Islam (IAIN) Kendari \\ supriyanto@iainkendari.ac.id
}

\begin{abstract}
Abstrak
Penelitian ini menggunakan pendekatan kualitatif dengan jenis penelitian studi kasus dan bersifat deskriptif yang bertujuan untuk mendeskripsikan dan menganalisis strategi penanaman karakter disiplin santri. Penelitian ini dilaksanakan di Pondok Modern Darussalam Gontor Kampus 7 Riyadhatul Mujahidin Pudahoa Mowila Konawe Selatan. Pengumpulan data penelitian dilakukan dengan tehnik wawancara, observasi dan dokumentasi. Analisis data dilakukan melalui reduksi data, display data dan verifikasi data. Pengecekan keabsahan data dilakukan melalui triangulasi sumber informasi, tehnik dan waktu. Hasil penelitian ini menemukan bahwa strategi penanaman karakter disiplin santri di Pondok Modern Darussalam Gontor Kampus 7 terbagi menjadi tiga yaitu: 1) disiplin berbahasa, 2) disiplin belajar dan 3) disiplin Ibadah. Ketiga strategi dalam penanaman karakter disiplin tersebut telah dilakukan secara maksimal, sehingga penelitian ini diharapkan dapat menjadi acuan/role model dalam penerapan disiplin santri khususnya pada pondok pesantren.
\end{abstract}

Kata Kunci: Strategi, Karakter Disiplin Santri, Pondok Pesantren.

\begin{abstract}
This study uses a qualitative approach to the type of case study research and is descriptive in nature which aims to describe and analyze the strategy of growing students' disciplinary character. This research was conducted at Pondok Modern Darussalam Gontor Campus 7 Riyadhatul Mujahidin Pudahoa Mowila Konawe Selatan. Research data collection was carried out with interview, observation and documentation techniques. Data analysis is performed through data reduction, data display and data verification. Checking the validity of the data is done through triangulation of information sources, techniques and time. The results of this study found that the strategy of cultivating the character of santri discipline in Pondok Modern Darussalam Gontor Campus 7 was divided into three namely: 1) language discipline, 2) discipline of learning and 3) discipline of worship. The three strategies in instilling the character of the discipline have been carried out to the maximum, so that this research is expected to be a reference/role model in the application of the discipline of students, especially in Islamic boarding schools.
\end{abstract}

Keywords: Strategy, Santri Discipline Character, Islamic Boarding School. 


\section{Pendahuluan}

Pendidikan merupakan suatu aspek penting bagi manusia, pendidikan bukan hanya sekedar transformasi ilmu dari guru ke murid, tetapi pendidikan adalah wadah dalam membentuk karakter atau kepribadian peserta didik (Fandi \& Haryanto, 2010). Oleh sebab itu pendidikan adalah proses yang berkesinambungan. Adapun pendidikan mempunyai tujuan yang akan memberikan arah dalam proses pendidikan dan tujuan tersebut dipaparkan dalam Undang undang Republik Indonesia Nomor 20 tahun 2003 tentang Sistem Pendidikan Nasional Bab 2 Ayat 3 yang menyatakan bahwa (Departemen Pendidikan Nasional, 2010): "Pendidikan Nasional berfungsi untuk mengembangkan kemampuan dan membentuk watak serta peradaban bangsa yang bermartabat dalam rangka mencerdaskan kehidupan bangsa, bertujuan untuk berkembangnnya potensi peserta didik agar menjadi manusia yang beriman dan bertaqwa kepada Tuhan Yang Maha Esa, berakhlak mulia sehat berilmu cakap kreatif dan menjadi warga negara yang demokratis serta bertanggung jawab.”

Dalam kaitannya dengan pendidikan Tilaar dalam Sofniyati mengemukakan bahwa pendidikan nasional dewasa ini sedang dihadapkan pada beberapa krisis pokok, yaitu menurunnya akhlak dan moral peserta didik, belum meratanya kesempatan belajar, masih rendahnya efisiensi internal sistem pendidikan, status kelembagaan, manajemen pendidikan yang tidak sejalan dengan pembangunan nasional serta sumber daya yang belum profesional (Syofniati, 2019)."

Karakter dalam pandangan Islam identik dengan akhlak yang merupakan tugas suci yang diemban oleh nabi utusan Allah, sebagaimana termaktub dalam sebuah hadits:

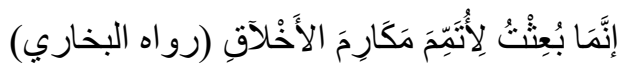

Terjemahannya: "sesunggguhnya aku diutus untuk menyempurnakan akhlak (budi pekerti) yang mulia"

juga tersirat jelas dalam QS. Al-Qalam/68: 4 Allah berfirman:

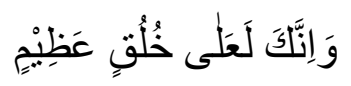

Terjemahannya: "Dan Sesungguhnya kamu benar-benar berbudi pekerti yang agung"

Mengingat pentingnya karakter dalam kehidupan manusia, maka hendaknya pendidikan karakter harus merupakan suatu proses yang berkelanjutan dan tidak pernah berakhir, sehingga menghasilkan perbaikan yang berkesinambungan dalam rangka 
menyempurnakan wujud manusiawi kita yang mengemban amanah menjadi khalifah Allah dimuka bumi ini. Ki Hajar Dewantara mengatakan, bahwa karakter anak merupakan bagian dari imu jiwa. Karakter seseorang bergabung dengan kodrat seseorang tersebut yang dipengaruhi oleh keturunan atau yang diwariskan oleh keluarga. Baik buruknya watak seseorang dapat dilihat dari jiwa dan dapat dipengaruhi oleh lingkungan (Dozan \& Fitriani, 2020).

Mengingat pentingnya karakter dalam kehidupan manusia, maka hendaknya pendidikan karakter harus merupakan suatu proses yang berkelanjutan dan tidak pernah berakhir, sehingga menghasilkan perbaikan yang berkesinambungan dalam rangka menyempurnakan wujud manusiawi kita yang mengemban amanah menjadi khalifah Allah dimuka bumi ini. Sebagimana ditegaskan oleh E Mulyasa dalam Meisusri Pendidikan karakter merupakan upaya untuk membantu perkembangan jiwa anak-anak baik lahir maupun bathin, dari sifat kodratinya menuju kearah peradaban yang manusiawi dan lebih baik (Meisusri et al., 2012). Kemendikbud tahun 2010 menyebutkan bahwa terdapat 18 karakter yang harus dimiliki oleh peserta didik yaitu karakter religius, jujur, toleransi, disiplin, kerja keras, kreatif, mandiri, demokratis, rasa ingin tahu, semangat kebangsaan, cinta tanah air, menghargai prestasi, bersahabat atau komunikatif, cinta damai, gemar membaca, peduli lingkungan, peduli sosial, dan tanggung jawab (Nurdin et al., 2022)

Salah satu lembaga pendidikan yang mengutamakan pendidikan karater dengan prosesnya 24 jam dalam sehari adalah Pondok Modern Darussalam Gontor. Pondok Modern Gontor memiliki perbedaan dengan Pondok Pesantren tradisional lainnya, yaitu lebih sistematis dan berdisiplin (Dini Handoko, 2018). Diantara yang membedakan antara Gontor dengan lembaga pendidikan yang lain adalah kurikulumnya menyeimbangkan antara ilmu agama dan umum, santri selalu berkomunikasi dengan bahasa Arab dan Inggris dan para santri tinggal di asrama dan berdisiplin (Jihan, 2014).

Disiplin merupakan elemen terpenting dalam pendidikan pesantren, ia merupakan sarana paling efektif dalam proses pendidikan lembaga ini, oleh karena itu disiplin harus ditegakkan oleh semua orang yang terlibat dalam pondok pesantren, baik santri, guru, maupun pengasuh pondok itu sendiri. Disiplin menyangkut beberapa aspek; disiplin berberibadah, berasrama, berpakaian, berolahraga dan berbahasa. Semua santri mutlak harus mentaati disiplin sejak pertama santri resmi menjadi bagian dari Gontor, kecuali 
disiplin bahasa yang diterapkan setengah tahun setelah santri baru tinggal di pondok (Mardiah, 2012).

Dengan adanya disiplin yang ketat menjadikan Pondok Modern Gontor lebih terasa kondusif dan teratur, serta suasana lingkungan tersebut dapat dijadikan sarana pendidikan yang efektif, segala sesuatu yang dilihat, dirasa, dan dikerjakan mengandung nilai-nilai edukatif. Para santri selalu dihimbau agar memperhatikan, melihat dan mengikuti segala kegiatan yang ada di pondok pesantren dan disuruh memperhatikan bagaimana cara hidup kiai, guru-guru dan atau ustadz-ustadz-nya (Syam, 2015).

Penelitian sebelumnya menemukan bahwa bahwa dalam menanamkan disiplin santri dilakukan dengan sosialisasi Sunnah disiplin, mengikis pelanggaran disiplin dengan absensi malam, Tahannuth sebagai media pembinaan disiplin dan melibatkan OSPA (organisasi santri pesantren al Basyariah) dalam penegakan disiplin (Tajiri, 2011). Sebagaimana dalam pendidikan karakter pada pondok pesantren salaf bahwa dalam membangun karakter santri dilakukan dengan melakukan kegiatan klasikan masrasiyyah ataupun ma'hadiyyah ini dianggap menjadi tulang punggung bagi arah keberhasilan santri (Zuhriy, 2011). Diniyah dalam penelitiannya bahwa strategi yang diterapkan UIN (Universitas Islam Negeri) Maulana Malik Ibrahim Malang adalah strategi dalam pendidikan karakter disiplin santri dilakukan dengan pendekatan sistem, hak dan kewajiban serta pendekatan emosional. Kedua, pola yang digunakan di pondok pesantren an-Nuriyyah dalam pembentukan karakter disiplin santri adalah otoritarian karena para santri berada di usia remaja (Diniyah, 2016).

Berdasarkan temuan di atas tentu saja penelitian ini memiliki kebaharuan dimana aspek yang akan difokuskan adalah penanaman disiplin adalah disiplin ibadah, berbahasa dan belajar dengan mengkaji strategi pelaksanaan ketiga aspek tersebut.

\section{Metode Penelitian}

Penelitian ini menggunakan pendekatan kualitatif dengan jenis penelitian studi kasus. Lokasi penelitian ini adalah Pondok Modern Darussalam Gontor 7 Riyadhatul Mujahidin Pudahoa Mowila Konawe Selatan. jenis data yang digunakan dalam penelitian ini adalah data primer, data sekunder. Teknik pengumpulan data dengan menggunakan Wawancara mendalam (depth interview), Observasi dan dokumentasi 
(Gunawan, 2013). Teknik analisis data menggunakan reduksi data, penyajian data, dan verifikasi data. Dalam penelitian ini, peneliti menggunakan pengecekan keabsahan data dengan menggunakan triangulasi, triangulasi yang digunakan adalah triangulasi sumber informasi triangulasi tehnik, triangulasi waktu, perpanjangan waktu penelitian (Mulyatiningsih \& Nuryanto, 2014).

\section{Karakter Disiplin}

Karakter adalah kata sifat yang menandakan ciri khas atau tipikal dari hal tertentu, yang mewakili diri seseorang atau sesuatu tentang perbedaan dan persamaan (Kesuma, 2011). Karakter yang baik berkaitan dengan mengetahui yang baik (knowing the good), mencintai yang baik (loving the good), dan melakukan yang baik (acting the good). Ketiga ideal ini satu sama lain sangat berkaitan (Sudrajat, 2011). Sedangankan Disiplin adalah keta'atan dan kepatuhan terhadap peraturan. Adapun penanaman disiplin adalah usaha untuk melatih dan mengajarkan seseorang untuk selalu bertindak sesuai dengan peraturan yang ada secara suka rela (Aeni, 2011). Menurut Charles Schaefer dalam Aulina disiplin adalah sesuatu yang mencakup pengajaran, bimbingan atau dorongan yang dilakukan oleh orang dewasa yang bertujuan untuk menolong anak belajar untuk hidup sebagai makhluk sosial dan untuk mencapai pertumbuhan serta perkembangan mereka yang optimal (Aulina, 2013).

Menurut Hurlock dalam Rohman tujuan disiplin adalah untuk membentuk perilaku sedemikian rupa hingga ia akan sesuai dengan peran-peran yang ditetapkan kelompok budaya dan tempat individu itu diidentifikasikan. Karena tidak ada pola budaya tunggal, tidak ada pula satu falsafah pendidikan anak yang menyeluruh untuk mempengaruhi cara menanamkan disiplin (Rohman, 2018). Jadi metode spesifik yang digunakan didalam kelompok budaya sangat beragam, walaupun semuanya mempunyai tujuan yng sama, yaitu mengajari anak bagaimana berperilaku dengan cara yang sesuai dengan standar kelompok sosial (sekolah), tempat mereka diidentifikasikan.”

Disiplin sangat penting dalam ajaran Islam. Bahkan dapat dikatakan bahwa Islam adalah agama disiplin. Hampir seluruh ibadah-ibadah Islammengandung unsurunsur pengajaran dan latihan-latihan disiplin. Kewajibanuntuk menunaikan shalat dengan syarat-syarat, rukun-rukun atau tata cara tertentujelas mengandung pelajaran dan latihan disiplin. Begitu juga ibadah puasa yangharus dikerjakan secara berdisiplin. Ibadah puasa akan meningkatkan kendali kontrol jiwa, baik dalam hubungannya dengan 
sesame manusia maupun dengan Allah. Karena itu, ibadah puasa akan meningkatkan disiplin sosial secarakeseluruhan. Selanjutnya, secara sederhana dapat dikemukakan bahwa di dalam Islam terdapat dua aspek disiplin: disiplin rohani (spiritual) dan disiplin moral (Rohman, 2018). Karakter disiplin merupakan sistem nilai terpola yang dimiliki oleh sekolah. Untuk memelihara agar pola nilai kedisiplinan tetap terpelihara dalam diri setiap anggota komunitas sekolah perlu dilakukan sosialisasi dan internalisasi (Wuryandani et al., 2014).

Menurut Prijodarminto dalam (Ihsan MZ, 2018) karakter kedisiplinan memiliki tiga aspek. Ketiga aspek tersebut adalah : a) Sikap mental (mental attitude) yang merupakan sikap taat dan tertib sebagai hasil atau pengembangan dari latihan, pengendalian pikiran dan pengendalian watak. b) Pemahaman yang baik mengenai sistem peraturan perilaku, norma, kriteria, dan standar yang sedemikan rupa, sehingga pemahaman tersebut menumbuhkan pengertian yang mendalam atau kesadaran, bahwa ketaatan akan aturan. Norma, dan standar tadi merupakan syarat mutlak untuk mencapai keberhasilan (sukses). c) Sikap kelakuan yang secara wajar menunjukkan kesungguhan hati, untuk mentaati segala hal secara cermat dan tertib (Kamila, 2013).

Menurut Charles Schifer tujuan karakter kedisiplinan ada dua macam yaitu: a) Tujuan jangka pendek adalah membuat anak-anak anda terlatih dan terkontrol, dengan mengajarkan mereka bentuk-bentuk tingkah laku yang pantas dan yang tidak pantas atau yang masih asing bagi mereka. b) Tujuan jangka panjang adalah perkembangan pengendalian diri sendiri dan pengaruh diri sendiri (self control dan self direction) yaitu dalam hal mana anak dapat mengarahkan diri sendiri tanpa pengaruh dan pengendalian dari luar (Tu'u, 2014).

Ada beberapa hal yang perlu dilakukan oleh guru untuk membentuk karakter disiplin pada peserta didik. Di antaranya adalah sebagai berikut: a) Konsisten. b) Bersifat jelas. c) Memperhatikan harga diri. d) Sebuah alasan yang bisa dipahami. e) Menghadiahkan pujian. f) Memberikan hukuman. g) Bersikap luwes. h) Melibatkan peserta didik. i) Bersikap tegas. j) Jangan emosional.

\section{Langkah-langkah Penanaman Karakter Disiplin}

Dalam pelaksanaan pendidikan karaker di pondok pesantren, paling tidak ada lima prinsip yang telah secara nyata dimilliki pesantren, yaitu: a) pesantren selama ini 
telah menjadi komunitas yang peduli terhadap pendidikan karakter, b) seluruh warga pesantren menjadi komunitas belajar dan komunitas moral yang merasa saling mempunyai tanggungjawab aakan berlangsungnya pendidikan karakter, c) memungkinkan bahkan mengharuskan para santri untuk melakukan tindakan bermoral, d) implementasi pendidikan karakter yang membutuhkan kepemimpinan moral telah terwakilli oleh Kiyai sebagai pengasuh atau pimpinan pesantren, dan e) antara pesantren, orangtua santri dan masyarakat telah terjalin 47 kohesi spritual dan rasa memiliki, sehingga saling bahu membahu, dalam kapaistasnya masing-masing dalam upaya pembangunan karakter (Johan, 2012).

Selain itu di dalam pesantren terdapat lingkungan yang sangat kondusif untuk mengembangkan karakter. Sebagaimana diungkapkan oleh E. Mulyasa dalam Hasyim lingkungan belajar yang kondusif memiliki peran yang sangat penting dalam mengembangkan dan membentuk pribadi peserta didik secara optimal, mulai dari penyadaran, pemahaman, kepedulian, sampai dengan pembentukkan komitmen yang tepat (Hasyim, 2014).

Timbulnya sikap kedisiplinan bukan merupakan peristiwa yang terjadi seketika. Kedisiplinan pada seseorang tidak dapat tumbuh tanpa intervensi dari pendidikan, dan itupun dilakukan secara bertahap, sedikit demi sedikit. Kebiasaan yang ditanamkan oleh orang tua dan orang-orang dewasa didalam lingkungan keluarga ini akan merupakan modal besar bagi pembentukan sikap kedisiplinan dilingkungan sekolah (Turban Yani, 2017). Jadi pada lingkungan pesantren, kebiasaan yang ditanamkan oleh pengasuh pesantren ataupun para pengurus sangatlah berat, karena akan menjadi modal besar bagi pembentukan sikap kedisiplinan di lingkungan pesantren.

Strategi Penanaman Karakter Disiplin Santri dalam disiplin bahasa, ibadah, dan belajar di Pondok Modern Darussalam Gontor kampus 7

\section{Disiplin Bahasa}

Strategi penanaman karakter disiplin santri dalam disiplin bahasa di Pondok Modern Darussalam Gontor kampus 7 menggunakan system Boarding School. Sistem pendidikan Boarding school dimaknai sebagai sistem pendidikan yang menjadikan sekolah sebagai asrama sekaligus tempat tinggal bagi siswa/santri untuk menuntut ilmu 
dan dibina selama 24 jam dalam sehari dengan melakukan seluruh aktifitas lembaga baik yang berupa formal maupun non formal.

Kegiatan penanaman karakter disiplin bahasa dilaksanakan dengan membuat jadwal berbahasa bagi para santri yaitu dua minggu untuk berbahasa Arab dan dua minggu berbahasa Inggris. Pada minggu berbahasa Arab, santri dibiasakan untuk berbahasa Arab, begitu pula dengan minggu bahasa Inggris. Pergantian minggu bahasa ditandai dengan pengumuman dimasjid pada hari jumat setelah shalat Maghrib. Selain itu, pemberian kosakata dilaksanakan setelah shalat subuh di asrama. Sistem pemberian kosakata ini dilakukan oleh pengurus asrama masing-masing dengan para santri mengikutinya sesuai dengan kelasnya. Sebagaimana keterangan salah satu pengurus yang mengatakan bahwa: "Setiap kelas dibimbing 3 (tiga) orang pengurus, satu orang sebagai pemberi kosa kata dan dua orang lainnya mengawasi. Setiap harinya para santri mendapatkan tiga kosa kata yang selanjutnya para santri diwajibkan untuk menggunakannya dalam percakapan sehari hari”.

Selain itu bagian bahasa OPPM (Organisasi Pelajar Pondok Modern) juga selalu memberikan pengarahan kepada santri agar meraka selalu aktif berbicara dengan temannya menggunakan bahasa Arab dan Inggris sesuai dengan kosakata yang telah diperolehnya. Karena tujuan pengarahan dalam jurnal Dunie adalah untuk membuat orang lain mengikuti keinginannya dengan menggunakan kekuatan pribadi atau kekuasaan jabatan secara efektif. Termasuk di dalamnya memberitahukan orang lain apa yang harus dilakukan dengan nada yang bervariasi mulai dari nada tegas sampai meminta atau bahkan mengancam. Tujuannya adalah agar tugas -tugas dapat terselesaikan dengan baik (Dunie, 2018).

Strategi dalam memperkaya perbendaharaan kosakata maka, para santri juga diharuskan untuk mencari sendiri setiap kosakata yang dibutuhkan serta diharuskan untuk membawa kamus atau kutaib (buku kecil yang berisi catatan kosakata) dimanapun dan kapanpun mereka berada, sehingga mereka bisa membacanya ketika waktu longgar atau mereka bisa langsung mencari arti dari kosakata yang belum diketahuinya (Observasi, 2019). Para guru pun juga selalu mengajak mereka berbicara dengan bahasa Arab dan Inggris. Maka dengan demikian terciptalah lingkungan yang kondusif berbahasa dan membuat santri baru cepat menguasai bahasa. Sebagaimana 
dalam konsep pembelajaran menurut Corey dalam Zuliana bahwa suatu proses dimana lingkungan seseorang secara disengaja dikelola untuk memungkinkan ia turut serta dalam tingkah laku tertentu dalam kondisi-kondisi khusus atau menghasilkan respns terhadap situasi tertentu (Zuliana, 2017).

Lingkungan yang ada di pondok sengaja diciptakan untuk mendidik terutama bahasa, disetiap sudut pondok ditempel kosakata-kosakata sesuai dengan lokasinya seperti contoh; di koperasi dapur, maka disitu ditempel kosakata yang berhubungan dengan peralatan dapur dan peralatan makan, begitu pula di koperasi pelajar maka dipasang di dinding kosakata yang berhubungan dengan barang-barang yang dijual di koperasi pelajar. Tujuannya adalah agar para santri selalu membaca, menghafalkan dan kemudian mempraktekkannya.

Selain lingkungan dan pemberian kosa kata maka pengawasanpun perlu diterapkan. Sebagaimana keterangan Arifuddin bahwa (Bako et al., 2018): "Pengawasan dan pengontrolan diasrama secara rutin dilaksanakan untuk memastikan para santri berdisiplin dalam berbahasa. Pengawasan ini dilakukan oleh bagian bahasa OPPM dengan cara keliling disetiap asrama setiap hari tiga kali sesuai kebutuhan. Fungsi dari pengawasan ini adalah agar para santri merasa terawasi sehingga mereka terbiasa dengan berbahasa resmi yaitu bahasa Arab dan Inggris".

Dalam pengawasan ini, apabila Bagian Bahasa OPPM menemukan santri yang melanggar disiplin berbahasa dengan berbicara bahasa Indonesia, maka bagian bahasa akan memanggilnya ke kantor bagian bahasa dan memberikan pengarahan berupa mauizoh atau nasehat serta ibroh. Dalam pemberian mauizoh ini santri yang melanggar akan dinasehati tentang pentingnya penguasaan bahasa untuk masa depannya serta pemberian ibroh berupa pengalaman para alumni sebelumnya yang telah sukses dengan penguasaan bahasa. Dengan memberikan mauizoh dan ibroh ini diharapkan para santri bisa sadar akan pentingnya disiplin berbahasa dan menguasai Bahasa. Apabila nantinya melanggar untuk kedua kalinya mereka akan mendapat hukuman berupa menulis 50 mufrodat yang diambil dari kamus kemudian menghafalkannya. Dan apabila melanggar untuk ketiga kalinya akan diberikan sanksi yang lebih berat lagi berupa botak atau dicukur rambutnya sampai habis.

Metode uswah hasanah (contoh yang baik) juga digunakan dalam penanaman karakter disiplin bahasa di pondok ini. Dalam hal ini para guru menjadi teladan bagi 
para santrinya dengan berkomunikasi dengan menggunakan bahasa resmi Arab dan Inggris sehingga bisa dicontoh oleh santrinya. Uswah hasanah ini bukan saja dari guru tetapi juga dari mulai dari Wakil Pengasuh, guru, pengurus OPPM dan pengurus asrama. Sehingga dengan demikian tercipta suasana yang kondusif untuk penanaman karakter disiplin berbahasa (Observasi, 2019).

Selain itu juga diselenggarakan berbagai macam perlombaan yang berkenaan dengan program peningkatan bahasa, seperti lomba drama contes antar asrama dengan berbahasa Arab maupun Inggris, lomba pidato bahasa Arab maupun Inggris, lomba membaca puisi bahasa Arab maupun Inggris, lomba muhadatsah dengan bahasa Arab maupun Inggris, sehingga dengan demikian akan terseleksi siapakan diantara santri yang cakap dalam berbahasa. Disamping itu santri yang selalu aktif dalam berbahasa akan diberi apresiasi/reward berupa piagam pengahargaan dan juga beasiswa.

Berdasarkan keterangan di atas jelas bahwa penanaman disiplin ada reward dan ada funishment. Pemberian pahala (reward) bagi manusia unggul dalam konteks pendidikan kiranya memperoleh pembenaran teologis (theologis justivication). Menurut Wens Tanlain dalam Hamid, reward adalah tindakan pendidik yang berfungsi memperkuat penguasaan tujuan pendidikan tertentu yang telah dicapai oleh anak didik. Tindakan ini merupakan pengakuan setuju terhadap yang telah dilakukan dan dicapai oleh anak didik. Agama Islam sendiri mengandung konsep pahala dan dosa untuk mengukur kualitas hidup manusia beriman. Konsep reward dan punishment merupakan pengukuran pendidikan bagi kualitas fungsional edukatif siswa yang berprestasi dan bermasalah. Hadiah, penghargaan, dan cenderamata adalah urgen diberikan kepada mereka yang berprestasi. Sebaliknya, hukuman sebagai vaksinasi dini dalam konteks pendidikanpun layak diberikan kepada mereka yang bermasalah.

\section{Disiplin Ibadah}

Dalam penanaman karakter santri dalam disiplin Ibadah menggunakan system yang kurang lebih sama dengan system yang digunakan pada disiplin bahasa, yakni system boarding School (asrama) yang juga diawasi langsung oleh para guru atau ustadz-ustadz yang ada di dalam pondok berdasarkan sistem pengasuhan.

Adapun dalam hal berdisiplin ibadah para santri tidak hanya diajarkan melalui lisan dan pengarahan saja akan tetapi juga langsung mempraktekkannya (learning by 
doing) yang dicontohkan oleh kyai dan guru-guru di pondok ini, karena kyai merupakan public figure dan teladan yang baik (uswah hasanah) dan yang paling ideal untuk menjadi panutan bagi para santri. Hal ini sama seperti pepatah yang mengatakan bahwa guru itu adalah singkatan dari bahasa jawa digugu dan ditiru (dicontoh dan menjadi teladan).

Strategi penerapan berdisiplin ibadah para santri selalu dibimbing dan dikawal karena kehidupan santri selama 24 jam dalam sehari tidak lepas dari pendidikan kedisplinan yang selalu didasari oleh nilai-nilai dan ajaran-ajaran kepondokmodernan. Pengendalian kedisiplinan santri semacam ini tidak lain dimaksudkan untuk mendidik tingkat kesadaran santri. Kesadaran adalah sangat penting yang selalu harus ditanamkan dalam diri santri, sehingga mereka melaksanakan ibadah bukan karena paksaan atau sekedar ikut-ikutan teman-temannya.

Strategi selanjutnya ialah dalam pelaksanaan sholat lima waktu bahwa tidak semua santri melaksanakan sholat berjamaah di masjid. Pada waktu magrib dan subuh seluruh santri dari kelas satu sampai kelas 6 melaksanakan solat berjamaah di masjid jami'. Adapun untuk waktu dzuhur, Ashar dan Isya para santri dari kelas satu sampai kelas 5 shalat berjamaah di asramanya masing-masing. Pelaksanaan shalat berjamaah di asrama ini dimaksudkan adalah untuk melatih santri menjadi muadzin dan imam sholat (Observasi, 2019).

Untuk mengendalikan kedisiplinan santri dalam beribadah, maka diperlukan pengawasan. Pengawasan penanaman nilai karakter kedisiplinan di pondok ini terdiri dari berbagai cara, ada pengawasan dengan jasus, ada dengan mahkamah, ada pengawasan dengan absen, ada pengawasan dengan cara evaluasi bertahap, dan ada juga pengawasan dengan keliling atau control, semua itu dilakukan untuk menciptakan suasana santri yang tertib berdisiplin.

Pengawasan dengan cara jasus, merupakan cara yang unik dalam penanaman nilai karakter kedisiplinan santri di pondok Modern Gontor 7. Medianya adalah para santri yang melakukan pelanggaran disiplin. Mereka diberi secarik kertas dan disuruh untuk mencari dua orang temannya yang melanggar disiplin, dan apabila mendapatkan temannya yang melanggar disiplin, maka ditulis nama, pelanggar, jenis pelanggaran, dan kapan pelanggaran itu terjadi. 
Pengawasan dalam hal lainnya adalah pengawasan dengan menggelar sidang (mahkamah) bagi setiap pelanggar kedisiplinan, sebagaimana yang dikemukakan oleh Alfadino yang mengatakan bahwa: "Pengawasan dengan cara mahkamah ini, dilaksanakan setiap setelah maghrib, digelarlah mahkamah bagi mereka yang terpanggil ke bagian keamanan, bentuk pelanggarannya pun bermacam-macam, dari mulai pelanggaran ringan, sedang, bahkan sampai ke pelanggaran berat. Didalam mahkamah tersebut, santri tidak hanya dihukum, tapi mereka juga diberi arahan-arahan, dipahamkan kembali akan pentingnya berdisiplin di Pondok Modern Gontor 7”.

Pengawasan dengan cara mahkamah tersebut bisa dikatakan efektif, karena sasaran utamanya adalah mengarahkan kembali kepada santri akan pentingnya berdisiplin dalam kehidupan di Pondok Modern Gontor 7.

Pengawasan lainnya yaitu dengan cara keliling atau inspeksi. Dalam bahasa Arab, sering disebut dengan kata daur. Pengawasan ini dilakukan oleh para pelaksana kedisiplinan santri dari bagian keamanan dan pengasuan santri. Dibagian keamanan, dengan jumlah personilnya yang cukup banyak, mereka membuat jadwal keliling perkelompok. Masing-masing punya giliran keliling dengan wilayah mana yang harus dikelilingi. Cakupan wilayah meliputi seluruh area pondok dan ruang-ruang kegiatan santri maupun di luar yang masih termasuk kompleks pondok. Mereka harus memastikan keadaan dan kondisi pondok saat itu aman dan terkendali dengan baik, tertib dan damai (observasi, 2019). Pengawasan yang lain yaitu dengan cara absensi. Tidak kurang lima kali dalam sehari, dibaca absen pada tiap-tiap waktu solat. Begitu juga di asrama. Dengan cara ini cukup efektif untuk mengetahui santri yang berdisiplin dalam beribadah apa tidak. Anak sejak dini harus diajarkan kegiatan-kegiatan keagamaan agar mereka tumbuh dengan budaya agamis. Wardani menjelaskan anak usia dini merupakan usia masa keemasan, maka anak harus diberikan latihan-latihan keagamaan melalui kegiatan berdoa, beribadah serta berperilaku sesuai ajaran agama, sehingga diharapkan anak akan menjadi taat beribadah terhadap ajaran agamanya. Apabila latihan itu dilalaikan sejak kecil atau dengan cara yang kurang tepat, maka ketika mereka menginjak usia dewasa nanti tidak akan memiliki kepedulian yang tinggi pada kehidupan beragama dalam kesehariannya (Andreas Putra et al., 2020). 
Mengendalikan santri dengan jumlah yang banyak memang tidak mudah. Maka dibutuhkan pengawasan berjenjang. Komando semua terpusatkan di staf pengasuhan santri, kemudian di bagian keamanan, pengawasan ini dapat berjalan dan berfungsi dengan baik, karena terus dikontrol dan dievaluasi. Laporan harian, mingguan, bulanan, dan tahunan menjadi media untuk monitoring dan kontrol.

Berdasarkan keterangan di atas jelas bahwa aspek pengawasan menjadi aspek penting dalam penerapan disiplin sebagaimana Menurut Murdick dalam Bako pengawasan merupakan proses dasar yang secara esensial tetap diperlukan bagaimanapun rumit dan luasnya suatu organisasi. Proses dasarnya terdiri dari tiga tahap:1) Menetapkan standar pelaksanaan. 2) Pengukuran pelaksanaan pekerjaan di bandingkan dengan standar. 3) Menentukan kesenjangan (deviasi) di antara pelaksanaan dengan standar dan rencana (Bako et al., 2018).

Selanjutnya adalah strategi penerapan disiplin dengan evaluasi dilakukan setiap dua kali dalam seminggu. Disana bagian keamanan mengevaluasi siswa kelas 5, selain itu membicarakan tentang administrasi, program, masalah keuangan, dan lain-lain. Selain itu, evaluasi dilakukan juga seminggu dua kali oleh ketua asrama bersama bagian keamanan yang dilakukan setiap hari rabu malam dan kamis malam.

Menurut Sarwoto dalam Mustofa keberhasilan suatu program pembelajaran tidak hanya dinilai dari segi hasil belajar peserta didik, tetapi juga dilihat dari sisi lain, yakni dari keberhasilan proses kegiatan yang telah dilaksanakan dan sesuai dengan rencana awal yang telah ditetapkan. Dalam hal ini pengawasan dan evaluasi program sangat berperan penting dalam menunjang keberhasilan pelaksanaan ptogram sebagai penentuan apa yang sudah tercapai (Mustofa et al., 2019).

\section{Disiplin Belajar}

Penerapan karakter berdisiplin belajar Di Pondok Modern Darussalam Gontor kampus 7, para santri dibina secara kontinyu dengan pengawasan selama 24 jam siang dan malam dalam seharinya. Selama proses belajar mengajar berlangsung diawasi dan dikontrol langsung oleh Wakil Direktur, guru senior dan staf KMI. Dalam proses pengawasan ini guru senior mengawasi dan mengontrol guru-guru yang sedang mengajar dikelas. Hal ini dimaksudkan agar para guru mengajar sesuai metode yang telah ditetapkan di Gontor. Sedangkan para santri juga dikontrol belajar mereka dikelas, agar mereka terkondisikan untuk belajar dan tidak ada yang ngantuk di kelas. 
Strategi penanaman karakter disiplin belajar santri, Gontor menerapkan wajib belajar malam bagi seluruh santri yang dilaksanakan setelah shalat 'isya' mulai pukul 20.00-21.30 WIB bertempat dikelasnya masing-masing. Aktifitas ini ditunggui oleh wali kelas atau wakil wali kelas masing-masing. Meskipun berkumpul dalam satu kelas, yang dipelajari siswa malam itu tidak sama, melainkan pelajaran apa saja yang ingin dipelajari para santri. Jika ada kesulitan, para wali kelas itu yang akan menjawab atau memberikan jalan keluar. Bahkan terkadang, acara muwajjah juga diisi dengan tasyji', yakni semacam pemberian motivasi dari wali kelas tentang belajar di Gontor, motivasi apa saja, bisa motivasi belajar, motivasi beribadah, atau motivasi mondok, bahkan motivasi hidup. Hasilnya, jelas efektif, jika para wali kelasnya aktif dan kreatif (Observasi, 2019).

Berdasarkan keterangan Irfanudin menjelaskan bahwa: Wakil Direktur Kulliyatul Mu'allimin al-Islamiyah (KMI) pun keliling untuk mengontrol pelaksanaan muwajjah ini, dan akan menegur wali kelas jika tidak melaksanakannya, juga merupakan ajang persaingan antarwali kelas. Siapa yang terbaik, paling kreatif, paling tekun membimbing siswanya, akan terlihat dari meningkatnya prestasi belajar siswa pada ujian pertengahan dan akhir tahun. Lebih jelas lagi, hal itu akan terlihat dari berapa jumlah siswi yang naik kelas.

Selain itu, dalam rangka penanaman karakter disiplin santri dalam disiplin belajar juga diterapkan dengan sistem pengasuhan. Sistem pengasuhan dalam hal belajar ini dipegang dan dijalankan oleh wali kelas masing-masing yang merupakan pendidik, pengawal dan pembina secara langsung atas berjalannya seluruh kegiatan aktifitas belajar santri di pondok ini baik didalam kelas maupun di luar kelas. Menurut penuturan informan mengatakan: "Dalam hal belajar para wali kelas mewajibkan anak didiknya untuk menghafalkan seluruh mata pelajaran. Tentunya bukan hanya dihafalkan saja tetapi juga dipahami. Maka para guru atau asatiz menekankan kepada seluruh santri untuk memahami seluruh mata pelajaran terlebih dahulu baru kemudian mewajibkan untuk menghafalkannya. Adapun untuk pelajaran matematika, berhitung, para santri tidak perlu untuk menghafalkannya kecuali rumus-rumusnya dan cukup untuk memahaminya saja” 
Sedangkan metode setoran hafalan santri kepada guru, yaitu para santri mendapatkan buku mudzakirotul hifdzi atau buku untuk setoran hafalan kemudian para santri menyetorkan hafalannya kepada guru yang telah ditentukan. Apabila santri sudah menyetor hafalannya, guru akan membubuhkan tanda tangan di buku mudzakirotul hifdzi. Dalam hal ini wali kelas dibantu oleh tiga orang asisten wali kelas. Para santri menyetor hafalannya kepada guru yang sudah ditentukan sesuai dengan dengan kelasnya. Menurut penuturan informan mengatakan

Tujuan diwajibkannya santri menghafal pelajaran, adalah agar mereka mampu menguasai pelajaran itu, dan diharapkan mereka nanti bisa mengajarkannya kepada masyarakat setelah mereka tamat belajar di Gontor. Karena pada hakikatnya pelajaran di Gontor bukan hanya sekedar pelajaran akan tetapi juga merupakan ajaran yang harus diamalkan dan diajarkan kepada masyarakat.

Dalam proses penanaman nilai karakter disiplin belajar santri di Pondok Modern Gontor, pemberian pengarahan terhadap santri sebelumnya adalah mutlak dan sangat penting, sebagaimana yang dikemukakan oleh ustadz Ahmad Rajif yang mengatakan bahwa: 'Proses penanaman nilai karakter kedisiplinan baik disiplin ibadah belajar dan bahasa adalah dengan pengarahan, santri akan diberikan pemahaman terhadap seluruh kegiatan yang akan dilaksanakan, dan dievaluasi setelahnya untuk mengetahui proses pelaksanaan tersebut. Pemahaman ini sangatlah diperlukan, agar mereka mengerti untuk apa melaksanakan, bagaimana teknik pelaksanaan, dan bagaimana pelakasanaannya, dan apa isi serta filosofinya."

Siswanto dalam Talibo berpendapat bahwa pengarahan adalah suatu proses bimbingan, pemberian petunjuk, dan instruksi agar mereka dapat bekerja sesuai dengan rencana yang telah ditetapkan. Sehingga, pengarahan ini begitu penting bagi jalannya suatu kegiatan. Disamping itu, keteladanan juga ditekankan dalam hal ini. Karena keteladanan adalah upaya memberikan dan menjadi contoh yang baik bagi peserta didik(Talibo, 2018). Dalam kaiatannya dengan belajar ini, para guru berupaya untuk menjadi teladan dalam belajar, yaitu dengan sungguh-sungguh dalam membimbing belajar santri. Berdasarkan keteranga Syahid mengatakan bahwa: "Saya melihat para guru dengan ikhlas membimbing kami tanpa kenal waktu. Ada yang membimbing belajar di pagi hari setelah ilqo' mufrodat yaitu mulai jam 5.30-06.00 WITA, ada pula yang membimbing santri belajar pada malam hari setelah muwajjah yaitu dari jam 
22,00-23.00 WITA. bahkan ada yang mengajak anak didiknya untuk belajar pada jam tiga dini hari setelah menunaikan solat tahajjud".

Aspek penting lainnya adalah penugasan yang merupakan sarana penanaman disiplin belajar santri yang sangat efektif. Dengannya, santri akan terlatih, terkendali, dan termotivasi. Pemberian tugas ini berkenaan dengan pemberian pekerjaan kamar atau PR kalau di luar pondok dan tugas tugas-tugas lain yang berkenaan dengan belajar. Dengan penugasan ini akan menimbulkan dinamika yang tinggi, santri akan nampak lebih bergairah dan bersemangat dalam menjalankan disiplin belajar santri. Menurut data selama observasi para santri mengerjakan PR bersama-sama dengan temantemannya dan mereka saling membantu yang lain apabila salah satu temannya menemukan kesulitan dalam belajar.

Pembiasaan adalah sesuatu yang disengaja dilakukan secara berulang-ulang agar sesuatu itu dapat menjadi kebiasaan. Pembiasaan santri untuk berdisiplin belajar dapat dilaksanakan secara terprogram, sebagaimana dikemukakan oleh Al-Ustadz Ahmad Irsyad yang mengatakan bahwa: Para santri dibiasakan untuk berdisiplin dalam belajar, baik belajar di kelas atau pun muwajjah pagi maupun malam, hal ini dimaksudkan agar mereka terbiasa dengan cara belajar yang baik".

Dengan pembiasaan maka santri akan menjadi terbiasa dengan berdisiplin belajar. Meskipun diawal-awal mereka merasa terpaksa, akan tetapi apabila dilaksanakan secara berkesinambungan maka menjadi kebiasaan dan akan tumbuh kesadaran dalam diri sendiri. Dalam melaksanakan penanaman nilai karakter kedisiplinan belajar santri, pembiasaan santri akan lebih efektif jika ditunjang dengan keteladanan dari para guru dan para pengurus Oleh karena itu, pembiasaan dalam penanaman nilai karakter kedisiplinan santri di pondok ini tidak terlepas dari keteladanan. Dimana ada pembiasaan disana ada keteladanan. Sebagaiman William dalam Saeful Anwar mengilustrasikan bahwa karakter adalah otot dimana otot-otot karakter akan menjadi lembek apabila tidak pernah dilatih dan akan kuat dan kokoh apabila sering dipakai dan berlatih. Begitu pentingtingnya kebiasaan ini diterapkan dalam setiap kegitan positif yang dilakukan setiap hari (Anwar, 2018). 


\section{Penutup}

Strategi penanaman karakter disiplin santri di Pondok Modern Darussalam Gontor Kampus 7 dalam disiplin berbahasa dengan cara: membuat jadwal berbahasa, memberi pengarahan, mauizoh dan ibroh kepada seluruh santri, ilqo' mufrodat, membuat kosakata disetiap area pondok, mewajibkan membawa kamus atau kutaib (buku kecil), pengawasan, uswah hasanah dari guru, pengurus asrama dan OPPM dan pemberian Apresiasi. Adapun dalam disiplin ibadah, strategi yang digunakan adalah dengan cara memberikan pengarahan, mauizoh dan ibroh kepada seluruh santri tentang ibadah, uswah hasanah dari guru, pengurus asrama dan pengurus OPPM, pembiasaan dan pemberian apresiasi. Sedangkan strategi penanaman karakter disiplin belajar adalah dengan pengawasan, keteladanan, pembiasaan, mewajibkan muwajjah atau belajar malam terbimbing, penugasan dengan cara memberikan ulangan-ulangan harian atau mingguan, dengan mauizoh dan ibroh. Berdasarkan hasil penelitian ini maka diharapkan strategi penerapan disiplin santri ini bisa menjadi role model bagi lembaga pendidikan lainnya karena penerapan disiplin ini telah dianggap maksimal dalam pelaksanaannya. Selain itu, penelitian ini diharapkan bisa menjadi bahan evaluasi bagi lembaga pendidikan ini khususnya lembaga pendidikan Gontor.

\section{DAFTAR PUSTAKA}

Aeni, A. N. (2011). Menanamkan disiplin pada anak melalui dairy activity menurut ajaran Islam. Jurnal Pendidikan Agama Islam-Ta'lim, 9(1-20), 1-13.

Andreas Putra, A. T., Sufiani, \& Jahada. (2020). Transformasi Nilai Pendidikan Islam Anak di PAUD Sultan Qaimuddin Kendari Pada Masa Pandemic Covid 19. Murhum: Jurnal Pendidikan Anak Usia Dini, 1(1), 79-90. https://doi.org/10.37985/murhum.v1i1.8

Anwar, S. (2018). Strategi penanaman karakter disiplin santri di Pondok Modern Darussalam Gontor kampus 3 Darul Ma'rifat Kediri.

Aulina, C. N. (2013). Penanaman Disiplin Pada Anak Usia Dini. PEDAGOGIA: Jurnal Pendidikan, 2(1), 36. https://doi.org/10.21070/pedagogia.v2i1.45

Bako, F. M., Masrurah, F., Tuli, F., \& Arifah, D. (2018). Pengawasan Dan Evaluasi Program Bahasa Arab Di Pondok Pesantren. Arabi : Journal of Arabic Studies, 3(1), 61. https://doi.org/10.24865/ajas.v3i1.72

Departemen Pendidikan Nasional. (2010). Undang Undang No 20 tahun 2003 tentang system pendidikan Nasional. 
Dini Handoko, M. I. D. (2018). Lampung Juga Punya Pondok Pesantren. CV IQRO'.

Diniyah, U. N. (2016). Penanaman karakter disiplin santri dalam peningkatan kualitas hafalan al-Qur'an: Studi multikasus Pondok Pesantren Tahfid al-Qur'an anNuriyyah Kebonsari Sukun dan Ha'iah Tahfidz al-Qur'an Universitas Islam Negeri Maulana Malik Ibrahim Malang.

Dozan, W., \& Fitriani, L. (2020). Membangun Karakter Anak Usia Dini Melalui NilaiNilai Islam Dalam Tradisi Perang Timbung. Murhum : Jurnal Pendidikan Anak Usia Dini, 1(1), 1-15. https://doi.org/10.37985/murhum.v1i1.2

Dunie, W. (2018). Pengaruh Pengarahan Terhadap Produktivitas Kerja Karyawan Pada Pt. Telkom Belitang Oku Timur. Jurnal Aktual, 16(2), 107. https://doi.org/10.47232/aktual.v16i2.25

Fandi, A., \& Haryanto. (2010). Desain Pembelajaran yang Demokratis dan Humanis. Ar-Ruzz Media.

Gunawan, I. (2013). Metode penelitian kualitatif. Bumi Aksara.

Hasyim, M. H. M. (2014). Penerapan fungsi guru dalam proses pembelajaran. AULADUNA: Jurnal Pendidikan Dasar Islam, 1(2), 265-276.

Ihsan MZ. (2018). Peran Konsep Diri Terhadap Kedisiplinan Siswa. NALAR: Jurnal Peradaban Dan Pemikiran Islam, 2(1), 1. https://doi.org/10.23971/njppi.v2i1.915

Jihan, J. (2014). Pendidikan islam multikultural di pesantren (studi kasus pada pondok modern ittihadul ummah gontor poso. Istiqra: Jurnal Hasil Penelitian, 2(1), 95123.

Johan, M. (2012). Implementasi Pendidikan Karakter di Pondok Pesantren; studi Kasus di Tarbiyyatul Muallimin Al-Islamiyyah Pondok Pesantren Prenduan Sumenep. Thesis UIN Maliki Malang.

Kamila, M. Z. (2013). Penanaman Karakter Disiplin Dan Tanggung Jawab Siswa Kelas X Melalui Pembelajaran PAI di SMA Negeri 1 Prambanan. Skipsi. Fakultas Ilmu Tarbiyah Dan Keguruan. Universitas Islam Negeri Sunan Kalijaga Yogyakarta.

Kesuma, D. (2011). Pendidikan karakter: kajian teori dan praktik di sekolah. PT Remaja Rosdakarya.

Malik, O. (2012). Psikologi Belajar Mengajar. Sinar Baru Algensindo.

Mardiah. (2012). Kepemimpinan Kyai dalam Memelihara Budaya Organisasi (p. 203).

Meisusri, S., Asri, Y., \& Nst, M. I. (2012). Nilai Pendidikan Karakter dalam Novel Malaikat-malaikat Penolong Karya Abdulkarim Khiaratullah. Pendidikan Bahasa Indonesia, 1(1), 222-229. https://doi.org/10.24036/288-019883

Mulyatiningsih, E., \& Nuryanto, A. (2014). Metode penelitian terapan bidang pendidikan.

Mustofa, Y., Razimona, T., Nafi'ah, D. U., \& Arifa, Z. (2019). Pengawasan dan Evaluasi Program Bahasa Arab untuk Peningkatan Berkelanjutan di Universitas Islam Negeri Maulana Malik Ibrahim, Malang. Al-Ma'rifah, 16(2), 113-121. 
https://doi.org/10.21009/almakrifah.16.02.01

Nurdin, N., Jahada, J., \& Anhusadar, L. (2022). Membentuk Karakter melalui Kegiatan Ekstrakurikuler Pramuka pada Anak Usia 6-8 Tahun. Jurnal Obsesi: Jurnal Pendidikan Anak Usia Dini, 6(2), 952-959. https://doi.org/10.31004/obsesi.v6i2.1603

Nuriyatun, P. D. (2016). Jurnal Pendidikan Guru Sekolah Dasar Edisi 33 Tahun ke-5 (p. 180).

Rohman, F. (2018). Peran Pendidik dalam Pembinaan Disiplin Siswa di Sekolah/Madrasah. Ihya Al-Arabiyah: Jurnal Pendidikan Bahasa Dan Sastra Arab, 4(1).

Sudrajat, A. (2011). Mengapa pendidikan karakter? Jurnal Pendidikan Karakter, 1(1). https://doi.org/10.21831/jpk.v1i1.1316

Syam, A. R. (2015). Manajemen pendidikan kedisiplinan santri di Pondok Pesantren: Studi kasus di Pondok Modern Darussalam Gontor.

Syofniati, S. (2019). Implementasi Pendekatan Kontekstual Dalam Pembelajaran Geografi (Studi Deskriptif Pada Siswa Kelas Xi Ips 4 Sma Negeri 4 Pekanbaru). JPG (Jurnal Pendidikan Geografi), 6(1). https://doi.org/10.20527/jpg.v6i1.6996

Tajiri, H. (2011). Integrasi Kognitif dan Perilaku dalam Pola Penanaman Disiplin Santri di Pesantren Al- Basyariah Bandung. Al-Tahrir: Jurnal Pemikiran Islam, 11(2), 415. https://doi.org/10.21154/al-tahrir.v11i2.42

Talibo, I. (2018). Fungsi Manajemen dalam Perencanaan Pembelajaran. Jurnal Ilmiah Iqra', 7(1). https://doi.org/10.30984/jii.v7i1.606

Tu’u, T. (2014). Peran Disiplin Pada Perilaku Dan Prestasi Siswa. Grasindo.

Turban Yani, M. S. H. (2017). Strategi Sekolah dalam Membentuk Karakter Disiplin Siswa Melalui Pembiasaan Budaya Sekolah (Vol. 03, pp. 1341-1355).

Wuryandani, W., Maftuh, B., Sapriya, S., \& Budimansyah, D. (2014). Internalisasi Nilai Karakter Disiplin Melalui Penciptaan Iklim Kelas Yang Kondusif Di SD Muhammadiyah Sapen Yogyakarta. Jurnal Pendidikan Karakter, 2. https://doi.org/10.21831/jpk.v0i2.2793

Zuhriy, M. S. (2011). Budaya pesantren dan pendidikan karakter pada pondok pesantren salaf. Walisongo: Jurnal Penelitian Sosial Keagamaan, 19(2), 287-310. https://doi.org/10.21580/ws.19.2.159

Zuliana, E. (2017). Nilai-Nilai Karakter Dalam Pembelajaran Bahasa Arab. An Nabighoh Jurnal Pendidikan Dan Pembelajaran Bahasa Arab, 19(1), 127. https://doi.org/10.32332/an-nabighoh.v19i1.761 